\title{
The process of implementing answerability in contemporary Brazil
}

\author{
Ana Rita Silva Sacramento \\ Faculdade Anísio Teixeira de Feira de Santana / Colegiado de Administração \\ Feira de Santana - BA / Brazil \\ José Antonio Gomes de Pinho \\ Universidade Federal da Bahia / Núcleo de Pós-Graduação em Administração \\ Salvador - BA / Brazil
}

\begin{abstract}
The aim of this study was to characterize the trajectory of answerability in Brazil. In the light of studies based on the historical neo-institutionalism approach, formal institutional changes adopted at federal level between 1985 and 2014, and which favor the typical requirements of answerability - information and justification - were identified and analyzed through the content analysis technique. The conclusion is that the trajectory of answerability in contemporary Brazil can be characterized as continuous, primarily occurring through the layering strategy, and whose leitmotif, since its origin, has consisted of matters of financial and budgetary nature. Nevertheless, a recent influence of deeper democratic subjects on it has been observed.
\end{abstract}

KEYWORDs: answerability; accountability; institutional change.

O processo de implementação da answerability no Brasil contemporâneo

A pesquisa objetivou caracterizar a trajetória da answerability no Brasil. À luz de estudos que se apoiam na abordagem do neoinstitucionalismo histórico, alterações institucionais formais adotadas no plano federal, entre 1985 e 2014, que favorecem as exigências típicas da answerability — informação e justificação - foram identificadas e, mediante técnica de análise de conteúdo, analisadas. Conclui-se que a trajetória da answerability no Brasil contemporâneo pode ser caracterizada como contínua, constituída basicamente por meio da estratégia de layering, cujo leitmotiv, desde a sua origem, são as questões de natureza financeira e orçamentária, muito embora já se observe uma recente influência de matérias mais profundas da democracia sobre a mesma.

Palavras-chave: answerability; accountability; mudança institucional.

DOI: http://dx.doi.org/10.1590/0034-7612147614

(c) (1)

Article submitted on Mar. 24 2015 and accepted for publication on Dec. $23^{\text {rd }}, 2015$. 
El proceso de implementación de la answerability en el Brasil contemporaneo

La investigación tiene como objetivo caracterizar la trayectoria de la answerability en Brasil. A la luz de estudios que se apoyan en la abordaje del neoinstitucionalismo histórico, alteraciones institucionailes formales adoptadas en el plano federal, entre 1985 y 2014, que favorecen las exigencias típicas de la answerability — información y justificación — fueron identificadas y, mediante la técnica de análisis de contenido, analizadas. Se concluye que la trayectoria de la answerability en el Brasil contemporaneo puede ser caracterizada como continua, constituida basicamente por medio de la estrategia de layering, cuyo leitmotiv, desde su origen, son las cuestiones de naturaleza financiera y presupuestaria, aunque ya se observe una reciente influencia de materias más profundas de la democracia sobre la misma.

Palabras clave: answerability; accountability; cambio institucional.

\section{Introduction}

It is discernible that the Brazilian social, political, and economical context has gone through changes since the transitional process between military dictatorship and democracy began. Under the most different justifications - modernization of administrative management, fight against corruption, economic development, etc. — government after government have adopted measures that, in one way or the other, seem to contribute to the emergence of a new path in public administration, creating conditions for a rupture with the patrimonialist logic in which the Brazilian society and state have been circumscribed since their foundation. In this sense, answerability is considered one of the key elements for the setup of an environment of an effective institutional change in Brazil.

In this particular, however, the national panorama seems to be challenging, for answerability, as part of the accountability process, is also an integral concept of the theory of the glossary of contemporary democratic politics, "which presupposes a clear differentiation between public and private property" and "provides public management methods open to the participation of society" (Filgueiras, 2011:67-68), characteristics that, as it is known, are not usually acknowledged as typical to Brazil.

Therefore, in order to understand the meaning of the term answerability - a key concept for the present study - it is necessary to situate it in the concept of accountability. Although we still lack a word that precisely defines it in good Portuguese, accountability refers to the process that obliges public officers in the structure of democratic states to account for their acts so that society itself, through its institutions and according to the circumstances, can apply the proper penalties or rewards (Pinho and Sacramento, 2009). Based on Schedler's teachings (1999), accountability absorbs three essential matters: information, justification and punishment; the first two requirements - information and justification - referring to the dimension that the aforesaid author calls answerability; and the last one - punishment to the enforcement aptitude, that is, the institutional power that in democracies, is held by 
agencies to impose sanctions and loss of mandate or office on those who fail to fulfill their public duties. As it can be seen, there is an interdependence between the two dimensions of accountability, for unperceived practices are not susceptible of punishment (enforcement), this being one of the reasons for the requirement of information and justification (answerability) concerning the actions performed by the agents who hold public offices.

Therefore, it is inferred that answerability, besides constituting a sine qua non step for the beginning of the accountability process, faces hindrances to consolidate itself in systems that, although democratic, have a political culture strongly marked by patrimonialist and authoritarian practices, as is the case for Brazil. That being said, the present study intended to provide a solution for the following problem: How can the building of the answerability trajectory in contemporary Brazil be portrayed? In the light of studies linked to historical neo -institutionalism, especially the theory of gradual institutional change, our specific aim was to identify and analyze the formal institutional changes that occurred in Brazil, in the federal sphere, and that favor the typical answerability requirements - information and justification — in the period between 1985 and 2014.

Several reasons can be presented to justify studies of this nature, among which we can highlight the fact that the term answerability, as is the case with accountability, also does not have a direct translation in Brazilian Portuguese, a situation that indicates that efforts to apprehend it are still welcome and necessary in Brazil. As to the option for studies which support the historical neo-institutionalism, it was motivated by the fact that, besides recognizing the importance of official political institutions - some of these have been used as sources of evidence in this investigation - they "tend to form a conception of institutional development that focuses on the trajectories, the critical junctions and the unforeseen consequences" (Hall and Taylor, 2003:196), hence totally in line with the scope of this study. As to the research delimitation, the temporal aspect was defined considering that the first civil government after 20 years of military dictatorship begins in 1985, while the year 2014 closes a governmental period of the recently reelected president Dilma Roussef. The option for the federal sphere is due to the great influence it has on subnational entities.

Methodologically speaking, this is an explanatory study since there is little systematized knowledge about answerability in Brazil, especially under the viewpoint of the theory of gradual institutional change, as well as a descriptive one, for it aims to characterize that trajectory. As to the means, the research was bibliographical and documental since it made use of material available to the general public, legal documents (Federal Constitution, supplementary laws, decrees, etc.), and digital versions of annals hosted in governmental websites. With an eminently qualitative approach, the categorical analysis was the procedure adopted for the analysis of the information gathered, having as analytical units phrases and paragraphs contained in legal instruments which indicate, on the one hand, the public office holders' obligation of informing and justifying acts, and on the other hand, information and justification as a citizens' right. 


\section{Some aspects of the theory of gradual institutional change}

The idea that institutions play a relevant role in the workings of contemporary societies has been spread through studies that, guided by the neo-institutionalism contribution, attempt to explain the influence of institutions on the determination of results, whether economic, social or political. This approach of thought, acknowledged as not unified since it embraces three schools of thought - historical institutionalism, rational choice institutionalism, and sociological institutionalism - expanded from the 1980s on (Hall and Taylor, 2003:193), and "is based on two propositions: institutions make the difference, and are endogenous" (Przeworski, 2005:59).

But what are institutions? In general terms, institutions are the "rules of the game". Under the historical institutionalism viewpoint, institutions are "official and officious proceedings, protocols, rules and conventions inherent to the organizational structure of the political community or economy" (Hall and Taylor, 2003:196). North (1990) classifies them in two dimensions: those of formal character (formal rules), and those of informal character (informal constraints). Constitutions and Acts are some examples of formal (written) institutions mentioned by that author. Conventions and codes of behavior, on the other hand, exemplify informal institutions, which are developed with time in the bosom of society itself (not written). North (1990) teaches that in a world characterized by informational asymmetry, institutions are constraints that men impose on themselves in order to reduce the uncertainties in their interactions. (North, 1990).

Institutional change, however, is one of the controversies found in institutionalistic approaches. According to Rezende (2012), the foundations for the development of a neo-institutional theory of change were laid by Douglas North, author of the economic institutionalism, in the classic Institutions, Institutional Change and Economic Performance, in 1990, when, combining requirements of historical institutionalism and approaches to transactional costs, he interpreted the institutional change processes as incremental, for he believes that they materialize "through marginal adjustments to the complex set of norms, rules, and structures of voluntary obedience" (Rezende, 2012:42).

Pierson (2004), in turn, presents the concept of institutional development as a new analytical model that, according to Loureiro, Teixeira and Moraes (2009) and for being broader and containing certain specificities when compared to the concept of institutional change, allows an understanding of "transformations that go beyond individual actions", "taking into account the sequence of the processes and the variations in the pace of transformations that are more or less gradual and slow" (Loureiro, Teixeira and Moraes, 2009:741). Mahoney and Thelen (2010) also draw on analyses developed by historical institutionalists in order to conform. They consider the role performed by the actors involved in the process as well as their acting strategies, the theory of gradual institutional change, whose essential prerequisite admits that institutions not only emerge but also change subtly and gradually as time goes by (Mahoney and Thelen, 2010:1). Such changes, according to these authors, can standardize human behavior and create substantial political results. In this approach, institutions are con- 
ceived as instruments of power distribution that are swarmed with tensions since any rule that models individual action involves the distribution of resources for certain types of actors, and not for others (Mahoney and Thelen, 2010:9).

It must be remembered that two notions are dear to historical neo-institutionalists when they want to carry out analyses related to institutional change: critical junctures and path dependence. Critical junctures are "temporal settings that cause a realignment of the agents' strategic beliefs, preferences and choices concerning current institutional arrangements." (Rezende, 2012b:115). According to Fernandes (2007), it is all about a transition situation characterized by a context of profound change. In short, conjunctures are critical when they "function as inflexion points of the previous path" (Loureiro, Teixeira and Moraes, 2009:742), guiding institutional change.

Path dependence has to do with the influence of the heritage of past institutions upon current decision making. It refers to "historical processes that are characterized by paths or trajectories that once taken, are difficult to revert" (Loureiro, Teixeira and Moraes, 2009:741). Path dependence indicates that history matters in the institutional evolution of a country and barriers imposed in the architecture of certain arrangements tend to crystallize institutions since their reversion will demand the assumption of too high a cost, which would render it difficult to take a probable detour from the path already taken, even when other possible choices appear

However, for Mahoney and Thelen (2010:08) there is nothing self-perpetuating about institutional dispositions, as they are always susceptible to changes. These authors explain that whoever benefits from current institutional conditions may have an objective preference for their continuity, but holding them steady demands continuous mobilization for political support, as well as active effort to settle ambiguities in a favorable way, hence the reason for institutional change and stability being umbilically connected.

According to Mahoney and Thelen (2010), political context and institutional characteristics shape the agents of change and influence them in the choice of the kind of strategy to be adopted. Thus, in relation to the political context, firstly it is important to analyze whether the possibilities of veto by the ones involved in the process are strong or weak. As to institutional characteristics, it is worth checking whether the level of discretion in the interpretation and application of rules by the involved agents is low or high. In the light of this theory, it is from the combination of this analysis (political context and institutional characteristics) that the classification of the processes of gradual institutional changes results in four different types: displacement, layering, drift, and conversion.

Institutional change by displacement happens when new rules are introduced in place of the previous ones. According to the authors, such a change may occur either abruptly, as in revolutions, or through a gradual process, in which new institutions are introduced, generally by the agency of actors in a disadvantageous situation as to the status quo, and start to compete with the old ones until these are discredited. As an example of a gradual displacement situation, Mahoney and Thelen (2010) mention the advancement of institutions oriented to 
Chinese and Cuban markets, and explain that as more and more actors desert for the market model, they can slowly undermine the arrangement controlled by the State.

Change is said to occur by layering when new rules are introduced upon or are parallel with the ones in force. In this situation, the introduced rules are not totally new, as in the displacement model; instead, they are amendments, revisions or additions to the existing ones since the agents interested in change are not able to overcome the supporters of the status quo and to change the original rules. On the other hand, supporters of the status quo are not strong enough to prevent amendments and modifications to the original rules as well. It happens that, as time goes by, these new "layers" can amass, leading to a gradual institutional change. A well-known example in national literature about the use of this strategy in Brazil can be found in the studies by Loureiro, Teixeira and Moraes (2009), when the authors refer to the parallel administrations during Getúlio Vargas's second government and Juscelino Kubitschek's government, in the 1950s, as such. Another example, now pointed out by Loureiro and Abrúcio (2002), is the fiscal reformations that occurred until the year 2000. According to these authors, the fiscal reformations of that period were implemented as an increment, "and not as an abrupt and linear way of change" (Loureiro and Abrúcio, 2002:24). Pinho (1998) also highlighted how the introduction of a managerialist pattern in the State, during Fernando Henrique Cardoso's government (FHC), had to accommodate the still prevalent patrimonialistic parameters, generating a kind of coexistence of two different structures.

Drift is the type of change that occurs when the impact of the rules is altered because of changes in the environment where the institution is inserted. The example presented by Mahoney and Thelen (2010) is that of changes due to alterations in the population of electoral districts established in many democracies, which may cause problems such as inadequate or unfair proportional distribution of representatives in a legislative body, thus resulting in distorted electoral outcomes and increasing the representativeness of some districts in relation to others. As it can be seen, in this case, formal rules are not modified, but their impact suffers variations due to the agents' negligence in relation to outside changes that, as in the aforesaid example, occur according to the number of inhabitants of electoral districts.

Conversion is the situation in which current rules remain unaltered, as it occurs in the drift strategy, but are subject to reinterpretations, and are applied in a different manner, thus causing changes. This gap between the rule and its application, however, is not a result of the agents' negligence, as happens with the drift; instead, it is produced, according to Mahoney and Thelen (2010), by agents who strategically explore the ambiguities inherent to institutions, assigning them new purposes. Thus, in this model, what is altered is the purpose of the institution. Loureiro, Teixeira and Moraes (2009) teach that when there are hindrances to complete changes in institutionalized structures, "considerable changes in an institution's workings occur, even if there is formal continuity of its rules" (Loureiro, Teixeira and Moraes, 2009:742).

But what are the main types of agents that promote institutional changes? Mahoney and Thelen (2010) believe that two essential questions must be asked when one wants to 
identify them. Does the actor seek to preserve the current institutional rules? Does the actor comply with the institutional rules? Depending on the answer to these questions, four types of agents can be identified in the light of framework of the theory of gradual institutional change: insurgents, symbionts, subversives, and opportunists. Each of them is described below:

Insurgent agents are identified as those who deliberately struggle to eliminate institutions or current rules by actively and visibly mobilizing against them. This type of agent is typical of conflict situations, when sudden patterns of change occur, bringing about the fall of the institutional status quo in favor of radically new rules. The insurgents, therefore, are associated with changes of the displacement type, notwithstanding the fact that they may also agree to a gradual replacement of the status quo.

The symbiont type is associated with changes by drift and may be of two variants: parasites and mutualists. Symbiont parasite actors are those who explore an institution for private profit, even when they are dependent on the existence and broad efficacy of the institution to reach their profit. It means that the parasites themselves act in contradiction to the purposes of the institution, sapping it in the long run. The mutualists, on the other hand, break rules in order to support and sustain the purpose of the institution, compromising neither its efficacy nor its survival.

Subversives are the type of agents who attempt to replace an institution, but, in pursuing so, do not break its rules. Unlike insurgents, subversives act in a quite discreet way. Following institutional expectations and working within the system, they wait for the right moment to act. They may even appear to be supporters of the status quo, but they are not. This type of agent is usually associated to layering processes of change, however, depending on the characteristics of the institutional political context, they can also adopt the conversion and some kinds of negligence to promote changes by institutional derivation, which means that, in the pursuit for change, subversives are not limited to only one strategy.

Falleti (2010, quoted by Mahoney and Thelen, 2010), provides an example of gradual change promoted in Brazil by subversive agents. According to this analysis, the change from the fragmented yet centralized health system to the universal yet municipalized regimen (SUS) did not happen abruptly, with the transition from authoritarianism to democracy, neither was it the result of "heroic" agents operating "against all of the disparities" inside the institution. In that author's opinion, the subversives worked as infiltrators in the centralized system in order to create another system, whose logic is completely different from the previous one, and even takes advantage of crucial characteristics of the previous authoritarian institutions.

Opportunists in turn are those agents who have ambiguous preferences concerning institutional continuity. They neither actively seek to preserve institutions nor attempt to change their rules. Instead, by adopting a "wait and see" attitude, opportunists develop conversion strategies, for they explore every possibility within the system to achieve their goals. As a conclusion, a summary-chart is presented, which illustrates what has been said about the theory of gradual institutional change, since its prerequisites guided the analysis that will be presented ahead. 
Chart 1

The theory of gradual institutional change

\begin{tabular}{|cccccc|}
\hline $\begin{array}{c}\text { Political context } \\
\text { (power of } \\
\text { veto) }\end{array}$ & $\begin{array}{c}\text { Institutional Characteristic } \\
\text { (discretion to interpret and } \\
\text { apply current rules) }\end{array}$ & $\begin{array}{c}\text { Dominant } \\
\text { Agent }\end{array}$ & $\begin{array}{c}\text { Attempt to } \\
\text { preserve } \\
\text { current rules? }\end{array}$ & $\begin{array}{c}\text { Comply with } \\
\text { current rules? }\end{array}$ & Strategies \\
\hline Strong & High & Symbiont & Yes & No & Drift \\
& Low & Subversive & No & Yes & Layering \\
Weak & High & Opportunist & Yes/No & Yes/No & Conversion \\
& Low & Insurgent & No & No & Displacement \\
\hline
\end{tabular}

Source: Personal creation based on Mahoney and Thelen (2010).

\section{Challenges to the institutionalization of answerability in Brazil}

According to what was stated in the introduction, answerability is one of the dimensions of accountability, a concept that has long been waiting for a Portuguese translation. But a starting point for every discussion on this subject, when considering Brazil, has been the inspiring article by Anna Maria Campos, "Accountability: quando poderemos traduzi-la para o português?", published in 1990, thus still at the beginning of our re-democratization process. Although well-known, it is worth registering, for its didactic nature, the way Campos got into contact with the term accountability during her Master's program in the USA. The term puzzled her since she could not find its equivalent in Brazilian Portuguese. Having grasped its meaning in English, she realized the term did not exist in Portuguese, or rather in the Brazilian reality, because we lacked that concept (Campos, 1990). From such a confrontation emerged the article with the suggestive title aforesaid. After nearly 20 years, Pinho and Sacramento (2009) returned to the disturbing question posed by Campos, and concluded that, despite having made some progress, as it shall be shown ahead, we still had not incorporated the concept in the Brazilian political life.

Referring to Frederich Mosher's work (Democracy and the Public Service), Campos (1990) points out two types of responsibility involved in this process: one of an objective nature, the other of a subjective nature. While the latter is related to the requirement that the holder of a public office carries to account for their acts, the first — of objective nature - is related to an individual's or organization's obligation to another, to do something or have some kind of performance. According to this viewpoint, if the responsibility for accounting for one's acts "is not felt subjectively" (by the individual towards themselves) by the holder of the public office, then it shall be demanded by another individual, "from outside to inside" (Campos, 1990:33).

Other authors agree on this dyadic character of the responsibility in the process of accountability. Przeworski (1998), for instance, thinks that "not all of the holders of offices in the public sphere are motivated by personal interests, for many of them care for public welfare"; however, "the workings of institutions cannot rely on the goodwill of those who work in 
them" (Przeworski, 1998:41). So far, and based on the conception of institutions conceived by Douglas North, the responsibility for accountancy works as a constraint that is able to shape the interaction between the holders of public offices and citizens in democratic regimes. When felt subjectively, it would be an informal constraint, but when objectively required, it would be a sort of formal rule, that is, it assumes another status.

Moreover, from Schedler (1999) one can understand that accountability occurs through the realization of its three essential matters: information and justification (answerability) and punishment (enforcement). With specific regard to answerability, a dimension that this study aims to investigate, one knows from that author, that its meaning surpasses that of transparency since it expresses itself in the obligation that holders of public mandates have to inform and account for their acts. Filgueiras (2011) is of similar opinion when, in a riveting essay, he indicates the limits of the "politics of transparency" by affirming that, on its own, such politics does not provide a normative substratum for the concept of accountability. He argues that, although it is impossible to think of political responsibility without institutions being transparent toward citizens and in the reduction of information insufficiency between both of them, further information does not imply better citizens, as well as more transparent governments do not assure better and less corrupt governors since, as the same author warns us, information "is produced by agencies that allow an ideological use of transparency" (Filgueiras, 2011:75-83).

Under this viewpoint, it can be understood that, besides the accounting process of accountancy, answerability also contemplates the process of the exercise of authority by the citizens, transparency being reduced to one of the requirements of another, wider principle - that of publicity - which, according to that same author, "demands that policies and rules that are issued by the government occur in a process open to democratic decision, and that institutions be controlled by other institutions and by the citizens themselves" (Filgueiras, 2011:85).

Therefore, there is a logic in the reasoning that considers accounting for one's acts crucial to the implementation of accountability, for after all, as Bobbio (2000) reminds us, "democracy is the government of visible power"; in a constitutional state, public character is the rule, secrecy is the exception, the former being, by the way, the characteristic that distinguishes this model from the absolutistic state (Bobbio, 2000:98-101).

Such a practice, however, has not received the necessary emphasis in countries - Brazil included - whose current type of democracy Guilhermo O'Donnell qualifies as "delegable”, in the sense that they "fulfill Robert Dahl's criteria for defining a polyarchy, but are not, nor seem to be, evolving to representative democracies" (O'Donnell, 1991:26). In this paradigm, the idea of accounting for one's acts being obligatory to institutions, whether public or private, is an unnecessary hindrance to the full authority of the governors chosen to represent the whole of the nation (O'Donnell, 1991). In this particular point, it is salutary to resort to Przeworski's teachings (1998), which warn us about both the insufficiency of classical democratic institutions to assure accountability, and the possibility of improving the quantity and quality of information made available to citizens by means of institutional innovations (Przeworski, 1998). 
As it can be seen, the access to information and justification and the quality of these resources are acknowledged in the researched literature as first order prerequisites to the building of an authentic democratic accountability process. This does not mean, however, that, by themselves, information access and quality are sufficient, but simply that the next step of the process, enforcement, will be rendered hopelessly impaired without those conditions. Therefore, considered under a democratic viewpoint, the requirements of information and justification that together constitute answerability go beyond the mere task of reducing the informational asymmetry and the uncertainty in the interaction among agents, as Douglas North points out when characterizing institutions. This is not supposed to deny here the functional aspect of answerability, but to highlight that, as a dimension of accountability, its meaning is much vaster.

Thus, if, on the one hand, it can be expected that some agents act for the continuity of the status quo in "delegable" types of democracy, on the other hand, there is a possibility that certain agents might act in an attempt to alter it aiming at an effective democracy in which answerability plays a role. This disturbing state of affairs couples really well with the premises of the theory of gradual institutional change, which says that institutions not only appear, but also change, subtly and gradually, as time goes by.

Taking another step in opening a dialogue between this frame of reference and Brazilian reality, it should be remembered, as stated by Santos (1994), that "the Brazilian polyarchy limits itself to a small institutional stain circumscribed by a gigantic culture of dissimulation, diffuse violence and individual and familiar confinement" (Santos, 1994:80). In other words, the Brazilian situation shows, in the author's conception, how most of the institutions are apart from political life.

Sorj (2001) is of the same opinion, although under different frames of reference, and sees our institutional system as marked by two mechanisms: on the one hand, "the fragility and quick obsoleteness to which new institutions are doomed by the tendency of generating gaps [...] or by decay — for lack of material or political supportive resources or by their patrimonialistic use" (Sorj, 2001:24). The other mechanism expresses itself through an "enormous disposition and flexibility in the creation of new alternatives, usually engendered in order to fill those gaps, but without replacing or totally eliminating old institutions". The author claims that this has been the path of the Brazilian State "in its constant efforts of modernization", and also that "Brazil can make a positive impression for its constant renovation and room for new initiatives [...] or imprint a negative effect for its lack of solidity and continuity of any institutional efforts". Therefore, an appetite for institutional building can be identified, but it must be seen with reservations, since this building may be overloaded with gaps and a lack of effort in the affirmation of current institutions. It is as if there were a necessity for new layers of institutions, for the newly-created ones do not manage to juggle their functions. Thus, the author does not spare words to describe the "fragility of the institutional system" evidenced "by the flexibility with which rules are dealt with", which leads to a "demoralization" of the system (Sorj, 2001). 
In such a context, it is worth introducing a reflection by José de Souza Martins, who has long been studying the Brazilian reality, and in whose opinion we are a society of slow history, a feature of "a country that did not engage in truly historical revolutions, but by halves and incompletely" (Martins, 2011:8). In his opinion, "the landowning tendency of land property in Brazil continues to rule the foundations of Brazilian politics" "even through the action of non-landowners" (Martins, 2011). In other words, Brazil bears much of its past, of the perpetuation of a secular underdevelopment, in spite of its modernization. In this sense, he states that "we are a baroque society, ruled by the adornments of appearance" (Martins, 2011:14), which can refer us back to the profusion of legislation and institutions that, for their most part, only seem to work.

If all of this framework is applied to the matter of institutions, it will result in the verification that many are the Brazilian obstacles that must be overcome so that an answerability path can be successful to the point of guiding an effective institutional change. Although we have a society which changes "even radically in the surface", it persists, however, in the maintenance of "profound social structures - social relations, mentalities, and even deep-rooted institutions already mentioned - landmarks of thought and conduct founded in past ages" (Martins, 2011:19).

In practice, and when one brings the theoretical referential presented above to the specificity of the Brazilian historical process, one notices how the persistence of the past, of underdevelopment, is a mark in our situation, plotting against effective institutional change, even if it is intrinsically slow. In this kind of society, the political engagement of agents in implementing answerability is considered weak or even nonexistent. Hence it is possible to conclude that its formulation demands turning points and time to be gradually consolidated.

In closing this section, it seems befitting to go back to its beginning, when we discussed the nonexistence of a direct translation - neither linguistic nor conceptual - of the term accountability into Brazilian Portuguese, to affirm that the same applies to the word answerability, a term yet lacking translation into Brazilian Portuguese, which is not surprising, of course, for the latter is an element of the former.

\section{Analysis and results}

At first, it is convenient to discuss the episode identified in this study as the critical juncture that has triggered the trajectory of building answerability in Brazil: Assembleia Nacional Constituinte (National Constituent Assembly), hereafter ANC. As part of the list of commitments made by the coalition created in order to indirectly elect Tancredo Neves President, and José Sarney Vice-President, ANC's purpose was to design a new Constitution for the country that, at that period, was becoming democratic again. Convened in November 1985, ANC was established on February 1, 1987, and lasted one year and seven months, closing its work in September 1988. 
Several reasons allow us to consider ANC a critical juncture. First of all, it should be remembered that the Constitution in force so far was that of 1967 , enforced by the exception regime, while the 1988 Constitution, created by ANC, emerges in a re-democratization range. The conflicts that preceded and defined the political context which resulted in its convocation - the amnesty, the party reformulation, the campaign for Diretas and Tancredo Neves's indirect election, to mention just a few events - as well as its transience are some of the typical characteristics of critical junctures, as defined by Fernandes (2007), identified in ANC. Moreover, according to Brandão (2011), ANC was "marked by a long process of permanent negotiation between the new and the old rules, between the new and the old social and political actors", whose "limits were tested at every moment, sometimes placed in check, sometimes reaffirmed and renewed" (Brandão, 2011:44). ANC's stressful environment is a good representative of the conception of institutions, presented by Mahoney and Thelen (2010) as instruments of power distribution, and full of tensions.

At this point, it is also convenient to know a little bit about the profiles of the constituent agents. According to Brandão (2011), there is a general agreement on the "centrist" profile being dominant among ANC's parliamentarians. It is evidenced in the party composition, when one notes that the parties then considered somewhat leftists (PT, PCB, PC do B, and PSB) were represented by less than $25 \%$ of those parliamentarians. To get things worse, it is known that PMDB, the majority party in ANC, divided itself during the process, losing its lead to supra-party, conservative groups, being the Centrão the most expressive of them. The various studies to know "who is who" in ANC also indicate its nature as centrist. In order to have an idea, when the ideological self-definition of the constituent agents was investigated, only 5\% declared themselves radical leftists; 52\% moderate leftists, or center-leftists; $37 \%$ centrists; $6 \%$ moderate rightists, or center-rightists; and none declared to be radical rightists (Rodrigues, 1987, quoted by Brandão, 2011:60).

Florestan Fernandes contributes to the knowledge of popular perception concerning ANC by teaching that in such a "social kaleidoscope" one cannot observe homogeneous perceptions, since "even the left is attacked, for not having withdrawn from ANC yet" and the signature of its text "presents itself as a dilemma to be faced by the parties" (Fernandes,1988:88). What can be interpreted from that political context, combined with its actors' profiles, is that an abrupt, radical change of the status quo through ANC seemed to be impossible, and the only alternative for agents who were interested in promoting some kind of change would be the use of strategies pursuant to typologies proposed by the theory of gradual institutional change. Apparently, that was somehow perceived, for some important innovations concerning answerability were included in the constitutional text. This was the groundwork to classify such agents as subversives, the type which, according to the theory, by recognizing the strong power of veto existing in the political context, work within a system that aims to change the status quo. It is opportune to point out that the constitutional final text had 474 favorable votes, 6 abstentions, and only 15 contrary votes, at a session to which 64 constituent members were absent. It is known that the 15 discordant voters, all PT members, ended up signing the text, an indication that the dilemma experienced by the party during the process had been overcome. 
Besides the aforesaid elements of the constituent members' predominantly "centrist" profile, it is worth considering that all of the debates were held during a government which, although labeled New Republic, was in fact a transition government, where the "ghost" of a military return still hovered over the legislative houses and the nation. Therefore, although there was freedom, a veiled - or not - memory of military dictatorship persisted, which indicates that the Constitution was not created in full democratic conditions.

As it is known, ANC's output called Constituição da República Federativa do Brasil de 1988 (CF/88 - Constitution of the Federative Republic of Brazil), promulgated on October 5. CF/88 ensured some dispositions that favor answerability, specifically its articles 5, 37, and 216 - which directly relate to information requirement - and article 58 - which directly relates to justification requirement. Article 5 includes the access to information in the list of fundamental rights and guarantees, ensuring even habeas data, that is, the right that any citizen has to obtain "information related to the person of the petitioner, contained in records of databanks of government agencies or of agencies of a public character", as well as "the correction of data, when the petitioner does not prefer to do so through a confidential process, either judicial or administrative" (Brasil, 1988); article 37 established the principle of publicity as one of the principles that shall be obeyed by "the direct or indirect public administration of any of the powers of the Union, the states, the Federal District and the municipalities"; article 216 assigned the public administration the responsibility for managing governmental documents and making arrangements to allow their consultation to whomever may need it. Let us mention that CF/88 ensures to everyone, without any payment of fees, "the right to petition the Government in defense of rights or against illegal acts or abuse of power", and "the obtaining of certificates from government offices, for the defense of rights and clarification of situations of personal interest" (Brasil, 1988).

It will be noticed that the aforementioned articles are directly related to information requirement, declaring the access to information as everyone's right, publicity as a principle of public administration, and document management one of its administrative duties. It was interesting to see that the items dealing with the right of public information access and ensuring habeas data had their origin in the respective Propostas de Emendas Populares (PEP — Popular Amendment Proposals) n. 21 and n. 48 - both put forward by associative entities — which shows that subversive agents outside the Congress influenced ANC's parliamentarians in those subjects. Article 58, in turn, by ensuring the right of public audiences held by public entities, guarantees another answerability requirement - the justification of actions taken. According to César (2011), such an instrument, besides promoting a dialogue with social actors aiming to seek alternative solutions for problems that involve public interest, "can be useful in collecting further information or evidence (declarations, experts' opinions, documents, etc.) of certain facts" (César, 2011:359), that is, it offers the possibility of questioning.

However, it is the creation of the Sistema Integrado de Administração Financeira do Governo Federal (Siafi - Integrated System for Financial Administration of the Federal Government), in January 1987, that can be acknowledged as the first practical measure directly 
associated with the dimension of answerability, especially with the information requirement, in the studied period. It was observed that useful information to the Union's general balance and budget execution, as well as financial administration reports, essential documents in the set of public account demonstrations by the Presidency of the Republic to the National Congress, is obtained through this system, since its implementation.

The next episode that can be associated with answerability is the creation of the Politica Nacional de Arquivos Públicos e Privados (National Policy of Public and Private Archives), by means of Law 8159, of January 8, 1991. Also known as Lei dos Arquivos (Archives Act), this legal text materialized CF/88 article 216, establishing in its article 1 that Public Entities have as obligation the "documental management and special protection of archive documents, as instruments to support administration, culture, scientific development, and as elements of evidence and information", restating that everyone has the right to receive from public entities information of their own personal, collective or general interest, contained in documents in public archives, and establishing that consultation to public documents shall be granted by the Public Administration (Brasil, 1991). It is a curious fact that this Act derives from Bill of Law n. 4895, which was put forward by the Executive Power when General João Figueiredo was President of the Republic, on December 5, 1984, thus by the end of the dictatorial period, but which was only regulated in 2002, by means of Decree 4073/2002, during the democratic government presided by FHC.

Another step that should be mentioned as helping the answerability institutionalization in Brazil is the approval of Supplementary Law 101/2000, Lei de Responsabilidade Fiscal (LRF - Fiscal Responsibility Act), which 12 years after the promulgation of CF/88 regulated its article 163. Deriving from the Bill of Supplementary Law n. 18/1999, by the federal executive power, LRF was not supported by parties such as PT, PSB, and PC do B, but it was approved, without great alterations to its original project, in a process "marked by intense negotiation and bargaining throughout the last two years of the first FHC government", international pressure being "an exogenous variable that strongly influenced the actors' calculations" (Loureiro and Abrúcio, 2002:22). According to Taylor (2011), although impelled by the fiscal policy, LRF provided for a greater transparency concerning public expenditure, and augmented public information availability. In agreement with these authors, Sacramento (2004) states that LRF is in line with the conception of accountability as delineated by Schedler (1999), since aspects related to answerability are decisively present in its text, an example being the necessity of publication of reports (information), and realization of public audiences (justification), aspects that, according to this author, contribute to reduce the opacity of public management as practiced in Brazil, especially in the budgetary and financial execution.

The creation of an entity directly bound to the Presidency of the Republic, originally called Corregedoria Geral da União (Corregidor's Office General of the Union), in 2001, is another fact that has to be mentioned here, for its consequences. By means of Provisional Measure n. 103, of January 1, 2003, converted in Law n. 10683, of May 28, 2003, its name was altered 
to Controladoria Geral da União (CGU - Controller's Office General of the Union), and its titular holder was called Minister of State of Control and Transparency. It should be pointed out that the publicity given to audits that were carried out and the inclusion of corporations and individuals punished by entities of the Public Administration of the different federative spheres in the Cadastro Nacional de Empresas Inidôneas e Suspensas (Ceis - National Database of Non Idoneous and Suspended Corporations) are examples of actions performed by CGU which reinforce the possibility of information.

At this point, it is convenient to acknowledge the importance of the creation of the Portal da Transparência (Transparency Portal). By means of Decree n. 5482/2005, the Federal Executive Power took a significant step toward information, for in order to fulfill the objective of "conveying detailed data and information about the Union's budgetary and financial execution", the Transparency Portal, whose management is an incumbency of CGU, shall publicize the "expenses incurred by public entities of the federal public administration; the remittance of federal resources to the states, Federal District and municipalities; the operations for decentralization of budgetary resources in benefit of individuals and non-governmental organizations of any nature; and the credit transactions performed by official financial institutions of fomentation" (Brasil, 2005).

It was also noted that dispositions were added to LRF due to the transformation of a bill of law put forward by the Federal Senate, in 2004, into Supplementary Law n. 131, of May 27, 2009, known as Lei da Transparência (Transparency Act), which determined "the availability, in real time, of detailed information about the budgetary and financial execution by the Union, states, Federal District, and municipalities", giving society the opportunity of simultaneously accompanying the public budget execution. As it is clearly established in its contents, "members of the Federation shall guarantee access to information concerning public expenses and revenues to any individual or corporation" (Brasil, 2009).

Therefore, it has been noted that alterations in the Brazilian institutional framework concerning answerability did not occur abruptly, but through a slow unfolding of steps, by means of diverse measures. This fact reinforces the words by Martins (2011) about the difficulty of promoting historical revolutions in Brazil, and also confirms the basic prerequisite of the theory of gradual institutional change by affirming that institutions do not only appear, but can also be altered, slowly and progressively, as time goes by.

However, these initiatives seem to be insufficient as to make our public managers aware of the nature of information contents that shall be made available to the population. An evidence of it was the necessary creation of another instrument - Decree n. 7185, of May 27, 2010 - establishing the minimum quality standard of the integrated system of financial administration (Sistema - sistema integrado de administração financeira), in the sphere of each member of the Federation. This decree establishes in great detail which information concerning expenses and revenues Sistema shall generate in order to make it available in the electronic environment so as to allow wide public access (Brasil, 2010). Thus, it is observed that a considerable part of the institutional alterations implemented so far in this analysis was guided by the financial and budgetary execution approach. It is believed that such a position 
can be even justified, in view of the numerous scandals involving corruption and bad management of public resources which historically and generally permeate all of the powers of the State and government spheres in Brazil.

Other institutional alterations whose purposes are strongly related to answerability and need to be highlighted before completing this section are: Law n. 12527 (Lei de Acesso à Informação - LAI - Information Access Act) and Law n. 12528 (Comissão Nacional da Verdade — CNV — National Commission of Truth), both of November 18, 2011.

LAI, whose purpose was also the regulation of constitutional dispositions concerning information access, defines information as "data, processed or not, which can be used for knowledge production and transmission, contained in any means, support or format" (Brasil, 2011); provides typical answerability mechanisms; and contemplates the information requirement by determining that "any interested individual or corporation may petition public entities for access to information, by any legitimate means; the petition shall contain the petitioner's identification, and specify the required information" (Brasil, 2011). Justification in turn is guaranteed by the provision that determines that, if the petition is denied, it shall be accompanied by a written justification that shall contain information about the possibility of appeal, its terms and conditions, and the authority responsible for its judgment. It is worth adding that the petitioner is granted the right to obtain the full text of the decision that denies the access (original or copy).

In the Union's sphere, LAI was regulated by Decree n. 7724, of May 2012, which established the Controladoria Geral da União as the competent entity to analyze and settle appeals against the denial of access by Federal Public Administration entities. A report by that entity informs that from 1088 appeals judged until December 5, 2013, 360 were favorable to the petitioner, and 728 were denied, from which 137 did not meet the basic appeal prerequisites, and 591 had their reasons for denial by the appealed entity supported by Law (CGU, 2014).

Law 12528/2011 in turn created the National Commission of Truth (CNV) for the purpose of investigating "serious violations of Human Rights" occurred between September 18, 1946, and October 5, 1988 (Brasil, 2011b). CNV is another example of an institutional effort that favors answerability through the layering strategy, since this legal instrument, derived from Bill of Law n. 7376/2010, did not annul any aspects of Law n. 6683/1979 (Lei da Anistia - Amnesty Act) and is in harmony with Law n. 10559/2002 (Lei dos Direitos do Anistiado Político - Political Amnestied Individual's Rights Act) and Law 9140/1995, which considers dead people who disappeared during the period referred to by Amnesty Act. CNV, which by presidential assignment was composed of seven counselors, was active from May 2012 to December 2014, having as final outcome a report that, not considering its controversies, bears in our opinion a certain historical value. The three-volume report is available for access at the website <www.cnv.gov.br>.

Considering the exposition above, the following chart aims to summarize the timeline of the building of the answerability trajectory in Brazil in the studied period. 
Chart 2

Building of the answerability trajectory in Brazil

\begin{tabular}{|cll|}
\hline Period & \multicolumn{1}{c|}{ Main Occurrence } & President \\
\hline $1987-88$ & ANC (Critical Juncture) & José Sarney \\
1987 & Siafi & José Sarney \\
1988 & CF/88 & José Sarney \\
1991 & Archives Act (Lei dos Arquivos) & Fernando H. Cardoso \\
2000 & Fiscal Responsibility Act (Lei de Responsabilidade Fiscal - LRF) & Fernando H. Cardoso \\
2001 & Corrigidor's Office General of the Union (Corregedoria Geral da União) & Fernando H. Cardoso \\
2003 & Controller's Office General of the Union (Controladoria Geral da União) & Lula da Silva \\
2005 & Transparency Portal (Portal da Transparência) & Lula da Silva \\
2009 & Transparency Act (Lei da Transparência) & Lula da Silva \\
2010 & SISTEMA (quality of information) & Lula da Silva \\
2011 & Information Access Act (Lei de Acesso à Informação - LAI) and & Dilma Rousseff \\
& Commission of Truth Act (Lei da Comissão da Verdade - CNV) & \\
\hline
\end{tabular}

Source: Author's creation.

As it can be noticed, the character of the last two institutional alterations is based on deeper democratic values, unlike what happened to the greatest part of the alterations implemented until 2010, which were strongly influenced by the financial and budgetary approach. Still, it is to be highlighted that the main catalyst to the actors' adherence to the implemented changes was in fact CF/88 by creating a new legal system for different spheres of the country. Moreover, it would be logical to infer that the building of each of such events was permeated by conflicts and disputes typical of processes that cause some kind of institutional change. However, and according to what was stated in the introduction, the present investigation aimed to identify and analyze formal institutional alterations that favor the typical answerability requirements in Brazil, in the referred period. Thus, a more detailed analysis of the conflicts and disputes that certainly involved their actors would obviously demand another specific, deeper and more extensive analysis, that is, another research design, for it would go beyond the original scope of this study.

\section{Final considerations}

This study consisted in identifying and analyzing, in the light of studies linked to historical neo-institutionalism, formal institutional alterations occurred in Brazil, in the federal sphere, and which favor the typical answerability requirements - information and justification — in the period extending from 1985 to 2014, in order to characterize its trajectory. 
The study showed that dispositions contained in the Federal Constitution of 1988, an output of ANC, which in turn is acknowledged here as the critical juncture which triggered the answerability trajectory in Brazil, do not seem to be sufficiently understood by those who play a role in the Brazilian political context to the point of effectively recognizing information and justification as a public officers' duty and a citizens' right. As it was evidenced, several normative instruments, not necessarily new in their contents and, in a way, even repetitive, were introduced in order to regulate constitutional dispositions, showing that CF/88 by itself had formalized a possibility of answerability in Brazil, but the effective building of its trajectory has demanded additional efforts, as it still does.

It was observed that, throughout the greatest part of the last 30 years, moments of stability and of institutional change concerning answerability have always been associated in Brazil, due to the action of subversive agents who, acting within the system, contributed to the advancement of the answerability trajectory in the Brazilian ground, although without radically altering the status quo. Thus, it is admitted that important steps have been made in that direction, and that contemporaneous Brazil has considerable institutional landmarks, especially a framework of laws, entities and rules (see chart 2 above) pro-answerability.

However, it must be pointed out that the voracious Brazilian appetite for "institutional building" may either indicate an effective institutional advancement, which is not little for a country that has recently abandoned a dictatorial military regime and did not even possess instruments to guarantee the storing and management of documents, or that, if certain legislation "does not become popular", another shall have to be created in order to produce the effects of the original one, which refers back to the problem of "enforcement" inaptitude, enforcement being another term that, such as accountability and answerability, does not have direct translation into the Brazilian political language.

Considering everything that was investigated, our conclusion is that the building of the answerability trajectory in contemporary Brazil may be defined as continuous, although it reveals certain difficulties in its consolidation. Basically achieved through layering, a strategy that allowed the introduction, although slow and gradual, of a series of institutional measures, it can be noticed that such a building advances in Brazil and has today as guide not only matters of financial and budgetary nature, as in its origins, but also deep democratic subjects. However, it should be highlighted that the establishment of this new framework of laws and entities can also be seen as a legal entanglement settled on a society whose basis is patrimonialist, and where there is too much confusion and little effectiveness, thus expressing the persistence of conservative characteristics in institutional structures and confirming that Brazil is still a country of "slow history". Therefore, it is obvious that the effectiveness of such a framework will be dependent on the mobilization and use of efforts in that direction, but it suggests the necessity of future studies, especially because of the sharp corruption cases that, shocking national and international public opinion, insistently continue to take place nowadays. By the way, it suffices to remember that LRF, one of the most precious jewels of our institutional advancement in financial and budgetary matters, and which scented general 
consensus, has recently suffered an attempt to violation through a "trick", which shows that the building of answerability in Brazil is still a road of slow progress and at risk of retrocession.

\section{References}

BOBBIO, Norberto. O futuro da democracia. São Paulo: Paz e Terra, 2000.

BRANDÃO, Lucas C. Os movimentos sociais e a Assembleia Nacional Constituinte 1987-1988. Dissertação (mestrado) - Programa de Pós-Graduação em Ciência Política, Faculdade de Filosofia, Letras e Ciências Humanas, Universidade de São Paulo, São Paulo, 2011.

BRASIL. Constituição da República Federativa do Brasil de 1988. Disponível em: <www.planalto. gov.br>. Acesso em: 25 jan. 2014.

BRASIL. Decreto no 5.482, de 30 de junho de 2005. Disponível em: <www.planalto.gov.br > Acesso em: 12 fev. 2014.

BRASIL. Decreto no 7.185, de 27 de maio de 2010. Disponível em: <www.planalto.gov.br>. Acesso em: 12 fev. 2014.

BRASIL. Lei Complementar no 101, de 4 de maio de 2000. Disponível em: <www.planalto.gov. br>. Acesso em: 15 mar. 2014.

BRASIL. Lei Complementar no 131, de 27 de maio de 2009. Disponível em: <www.planalto.gov. br> . Acesso em: 3 fev. 2014.

BRASIL. Lei no 8.159, de 8 de janeiro de 1991. Disponível em: <www.planalto.gov.br>. Acesso em: 30 jan. 2014.

BRASIL. Lei no 12.527, de 18 de novembro de 2011. Disponível em: <www.planalto.gov.br> Acesso em: 2 abr. 2014.

BRASIL. Lei no 12.528, de 18 de novembro de 2011(b). Disponível em: <www.planalto.gov.br > Acesso em: 2 de abril de 2014.

CAMPOS, Anna M. Accountability: quando poderemos traduzi-la para o português? Rev. Adm. Pública, v. 24, n. 2, p. 30-50, fev./abr. 1990.

CÉSAR, João B. M. A audiência pública como instrumento de efetivação dos direitos sociais. RVMD, v. 5, n. 2, p. 356-384, jul./dez. 2011.

CGU. Coletânea de Decisões da CGU. Brasília. 2014. Disponível em: <www.acessoainformacao.gov. br>. Acesso em: 3 dez. 2014.

FERNANDES, Antônio S. A. Path dependency e os estudos históricos comparados. In: SIMPÓSIO NACIONAL DE HISTÓRIA, XXIV, 2007, São Leopoldo.

FERNANDES, Florestan. A percepção popular da Assembleia Nacional Constituinte. Estudos Avançados, v. 2, n. 2, p. 86-88, ago. 1988. Disponível em: <www.scielo.br> . Acesso em: 20 mar. 2014. 
FILGUEIRAS, Fernando. Além da transparência: accountability e política da publicidade. Lua Nova, n. 84, p. 65-94, 2011. Disponível em: <www.scielo.br>. Acesso em: 2 fev. 2014.

HALL, Peter A.; TAYLOR, Rosemary C. R. As três versões do neo-institucionalismo. Lua Nova, n. 58, p. 193-223, 2003.

LOUREIRO, Maria R.; ABRÚCIO, Fernando L. Incrementalismo, negociação e accountability. In: ANPOCS, 2002, Caxambu. Anais...

LOUREIRO, Maria R.; TEIXEIRA, Marco A. C.; MORAES, Tiago C. Democratização e reforma do Estado: o desenvolvimento institucional dos tribunais de contas no Brasil recente. Rev. Adm. Pública, v. 43, n. 4, p. 739-772, jul./ago. 2009.

MAHONEY, James; THELEN, Kathleen. A theory of gradual institutional change. In: MAHONEY, James; THELEN, Kathleen (Ed.). Explaining institutional change: ambiguity, agency and power. Cambridge: Cambridge University Press, 2010. p. 1-37.

MARTINS, José de S. A política do Brasil lúmpen e místico. São Paulo: Contexto, 2011.

NORTH, Douglass C. Institutions, Institutional Change and Economic Performance. Cambridge: Cambridge University Press, 1990.

O’DONNELL, Guillermo. Democracia delegativa? Novos Estudos — Cebrap, n. 31, p. 25-40, out. 1991.

PIERSON, Paul. Politics in time: history, institutions, and social analysis. Princeton: Princeton University Press, 2004.

PINHO, José A. G. de. Reforma do aparelho do Estado: limites do gerencialismo frente ao patrimonialismo. O\&S, v. 5, n. 12, p. 59-79, maio/ago. 1998.

PINHO, José A. G. de; SACRAMENTO, Ana R. S. de. Accountability: já podemos traduzi-la para o português? Rev. Adm. Pública, v. 43, n. 6, p. 1343-1368. nov./dez. 2009.

POWER, Timothy J.; TAYLOR, Matthew M. Accountability institutions and political corruption in Brazil. In: POWER, Timothy J.; TAYLOR, Matthew M. (Ed.). Corruption and democracy in Brazil: the struggle for accountability. Notre Dame: University of Notre Dame Press, 2011. p. 1-28.

PRZEWORSKI, Adam. A última Instância: As instituições são a causa primordial do desenvolvimento econômico? Novos Estudos - Cebrap, n. 72, p. 59-77, jul. 2005.

PRZEWORSKI, Adam. Sobre o desenho do Estado: uma perspectiva agent $\times$ principal. In: BRESSER-PEREIRA, Luís C.; SPINK, Peter K. (Org.). Reforma do Estado e administração pública gerencial. Rio de Janeiro: FGV, 1998. p. 39-73.

REZENDE, Flávio da C. Convergências e controvérsias sobre a mudança institucional. Revista de Sociologia Política, v. 20, n. 41, p. 37-51, fev. 2012.

REZENDE, Flávio da C. Da exogeneidade ao gradualismo: inovações na teoria de mudança institucional. RBCS, v. 27, n. 78, p. 113-194, fev. 2012(b). 
SACRAMENTO, Ana R. S. Contribuições da Lei de Responsabilidade Fiscal para o Avanço da Accountability no Brasil. In: ENANPAD, XXVIII, 2004, Curitiba. Anais...

SANTOS, Wanderley G. dos. Razões da desordem. Rio de Janeiro: Rocco, 1994.

SORJ, Bernardo. A nova sociedade brasileira. Rio de Janeiro: Zahar, 2001.

SCHEDLER, Andreas. Conceptualizing accountability. In: SCHEDLER, Andreas; DIAMOND Larry; PLATTNER Marc F. (Ed). The self-restraing state. Power and accountability in new democracies. Boulder. Londres: Lynne Rienner Publishers, 1999. p. 13-28.

TAYLOR, Matthew M. The evolution of accountability institutions in new democracies: Brazil's web of accountability, 1985-2009. In: CONGRESS OF THE LATIN AMERICAN STUDIES ASSOCIATION, 2009, Rio de Janeiro. Disponível em: <http://lasa-2.univ.pitt.edu/members/congress-papers/ lasa2009/files/TaylorMatthewM.pdf>. Acesso em: 15 fev. 2014.

Ana Rita Silva Sacramento has a PhD in administration at Federal University of Bahia's, Brazil / School of Administration. She is coordinator and professor at Anísio Teixeira Faculty at Feira de Santana / Administration Board. E-mail: ana.sacramentos@uol.com.br.

José Antonio Gomes de Pinho. PhD. LSE - University of London. Professor. School of Administration Federal University of Bahia (UFBA). Brazil. E-mail: jagp@ufba.br. 